University of Nebraska - Lincoln

DigitalCommons@University of Nebraska - Lincoln

USDA National Wildlife Research Center - Staff Publications
U.S. Department of Agriculture: Animal and Plant Health Inspection Service

2016

\title{
Photographic estimation of wild boar damage to alpine grazing pastures in the Carpathian Mountains of central Romania
}

Richard M. Engeman

USDA-APHIS-Wildlife Services, s_r100@yahoo.com

Renate Cattaruzza

Ruprecht-Karls-Universität Heidelberg, Institute for Physiology and Pathophysiology

Marco Cattaruzza

Ruprecht-Karls-Universität Heidelberg, Institute for Physiology and Pathophysiology

Justin W. Fischer

USDA/APHIS/WS National Wildlife Research Center, Justin.w.fischer@aphis.usda.gov

Follow this and additional works at: https://digitalcommons.unl.edu/icwdm_usdanwrc

Part of the Life Sciences Commons

Engeman, Richard M.; Cattaruzza, Renate; Cattaruzza, Marco; and Fischer, Justin W., "Photographic estimation of wild boar damage to alpine grazing pastures in the Carpathian Mountains of central Romania" (2016). USDA National Wildlife Research Center - Staff Publications. 1769.

https://digitalcommons.unl.edu/icwdm_usdanwrc/1769

This Article is brought to you for free and open access by the U.S. Department of Agriculture: Animal and Plant Health Inspection Service at DigitalCommons@University of Nebraska - Lincoln. It has been accepted for inclusion in USDA National Wildlife Research Center - Staff Publications by an authorized administrator of DigitalCommons@University of Nebraska - Lincoln. 


\title{
Photographic estimation of wild boar damage to alpine grazing pastures in the Carpathian Mountains of central Romania
}

\author{
Richard Engeman $^{1} \cdot$ Renate Cattaruzza $^{2} \cdot$ Marco Cattaruzza $^{2} \cdot$ Justin Fischer $^{1}$
}

Received: 19 August 2015 / Accepted: 4 January 2016 / Published online: 18 January 2016

(C) Springer-Verlag Berlin Heidelberg (outside the USA) 2016

\begin{abstract}
Observations of wild boar damage to alpine grazing pastures in Romania's Carpathian Mountains were collected using photographs of the slopes from vantage points. We mapped the rooted areas and then used GIS software to estimate the relative proportions of the total grazing areas visible in the photographs that were damaged by wild boar. The amounts of damage from our two demonstration pastures were 11.2 and $13.5 \%$. Pastures are rented for summer grazing with grazing density monitored. Wild boar damage essentially decreases the economic benefit received for the cost of the grazing rights. This paper appears to be the first documentation of the very direct costs to livestock owners from significant wild boar rooting within rented pastures. The photographic method we present provides a quick and efficient means to quantify damage to alpine grazing pastures and may have broad application for mountainous areas where swine damage (or other disturbance) occurs and there is sufficient visibility of the damaged habitat.
\end{abstract}

Keywords Animal damage $\cdot$ Feral hog $\cdot$ GIS $\cdot$ Sus scrofa . Swine rooting $\cdot$ Wild pig

Responsible editor: Philippe Garrigues

Marco Cattaruzza deceased.

Richard Engeman

richard.m.engeman@aphis.usda.gov

1 USDA/APHIS/WS National Wildlife Research Center, 4101 LaPorte Ave, Fort Collins, CO 80521-2154, USA

2 Ruprecht-Karls-Universität Heidelberg, Institute for Physiology and Pathophysiology, Im Neuenheimer Feld 326,

69120 Heidelberg, Germany

\section{Introduction}

A variety of methods is available to measure and estimate wild pig (wild boar, feral swine, Sus scrofa) damage to natural habitats. Some methods require locating each patch of damage in an area and very precisely measuring them to provide a near-exact damage assessment (e.g., Felix et al. 2014). Most methods, though, estimate damage through a sampling procedure, with examples including methods such as quadrat (Engeman et al. 2003; 2007) and line intercept sampling (Thomas et al. 2013). Remote photographic methods offer the possibility of measuring damage without physical presence at the damage sites, and include imagery collected from aircraft (helicopters and fixed wing), satellites and unmanned aerial systems (aka drones). Nevertheless, ground-truthing is required for a portion of the identified areas to estimate what percentage are actually damage caused by swine, with the percentage of potential damage areas that actually are caused by feral swine proportional to swine population density and activity. In mountainous areas, another possibility for lowcost, high-resolution image capture without using aircraft or satellite imagery is using high-resolution cameras to acquire imagery where an open slope may be photographed from a vantage point, usually on a nearby hillside. Here we demonstrate how this ground-based sampling technique can be accomplished using photographic observations of steep alpine pastures with wild boar damage in central Romania's Carpathian Mountains (aka, Transylvania).

Romania has a well-preserved natural heritage, especially in comparison to the rest of Europe. The Carpathian Mountains are well-known for substantial and healthy wildlife populations such as large carnivores (including brown bears (Ursus arctos), wolves (Canis lupus), and lynx (Lynx lynx)), as well as native ungulates including wild boar (Ionescu et al. 2009; Mertens et al. 2001; MAPDR and MMGA 2006; 
Predoiu and Ungurean 2010). Reports in the literature on human-wildlife conflicts in the Carpathian Mountains are centered on depredations of livestock by large carnivores on summer grazing pastures (Ionescu et al. 2009; MAPDR and MMGA 2006; Mertens et al. 2001; Predoiu and Ungurean 2010). However, we focus here on another form of loss caused by wildlife, which to our knowledge has not received attention in the literature to date: wild boar damage to alpine grazing pastures. In particular, we describe a quick and efficient means to measure this damage on the steep mountain pastures using photographs and then using GIS software to calculate a relative area damaged, similar to the approach of Felix et al. (2014) after mapping perimeters of damage areas using GPS devices.

\section{Methods}

\section{Study area and grazing practices}

While the Carpathian Mountains are rugged, lower altitudes often support small farms, dwellings, and some crops. Higher altitudes are forested with many interspersed alpine meadows. These areas are used as pastures for sheep and cattle grazing during the summer months (May to September). During this period livestock are organized and aggregated into larger groups for grazing in the mountains. Sheep represent the majority of livestock grazed (MAPDR and MMGA 2006), with around 5 million sheep grazed in the Romanian mountains (Ionescu et al. 2009; Mertens and Promberger 2000; Mertens and Schneider 2005; Promberger and Mertens 2001).

\section{Damage observations}

We visited alpine livestock grazing sites on foot in and around Piatra Craiului National Park near Zarnesti in central Romania (nearest major city, Brasov). A special feature of this park is to allow traditional methods of livestock farming within its borders (for comprehensive information see www.pcrai.ro). A negative and seeming ubiquitous impact on sheep grazing is wild boar rooting of the alpine grazing lands (Fig. 1). Whereas large carnivore damage to livestock has been welldocumented in the literature, impacts to grazing lands in the Romania's Carpathian Mountains by wild boar have not. Nevertheless, virtually every alpine meadow we observed had substantial portions rooted by wild boar.

Our approach was similar to that of Felix et al. (2014) in that it required use of GIS software to quantify damage amounts. The measurement method described by Felix et al. (2014) for highly accurate measures of feral swine damage requires first locating and then mapping feral swine damage areas with GPS. The areas of damage are subsequently calculated using GIS software. In the case of wild boar damage on

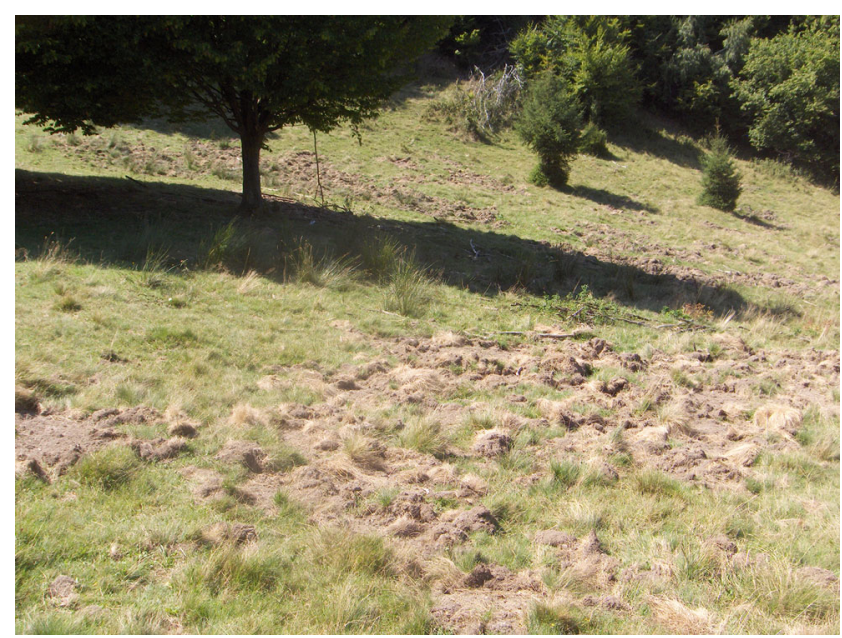

Fig. 1 Alpine meadow heavily damaged by swine in the Carpathian Mountains, Romania. (Photo by R. Engeman)

sloping alpine pastures, damage areas are readily visible and easily photographed from vantage points.

Using the photos in Figs. 2 and 3 for our examples, we mapped (outlined) the rooted areas and then used ArcGIS 10.0 software (Environmental Systems Research Institute, Redlands, CA, USA) to estimate the relative proportions of the total grazing areas visible in the photographs that were damaged by wild boar. These example-pastures each show a complete or near-complete view of a hillside pasture, which allowed observation of wild boar damage for our purposes. Fig. 2 shows a relatively straight-on view of a typical alpine meadow used for grazing, and thereby probably presents minimal bias in damage proportion calculations. In Fig 3, the view is looking across the meadow which also has a downward slope. Since most of the damage is either beyond the foreground of the photo or down the slope of the hill, the GISmeasured damage areas tend to be biased small, making proportion calculations likely biased low (conservative) and a lower bound for the true amount.

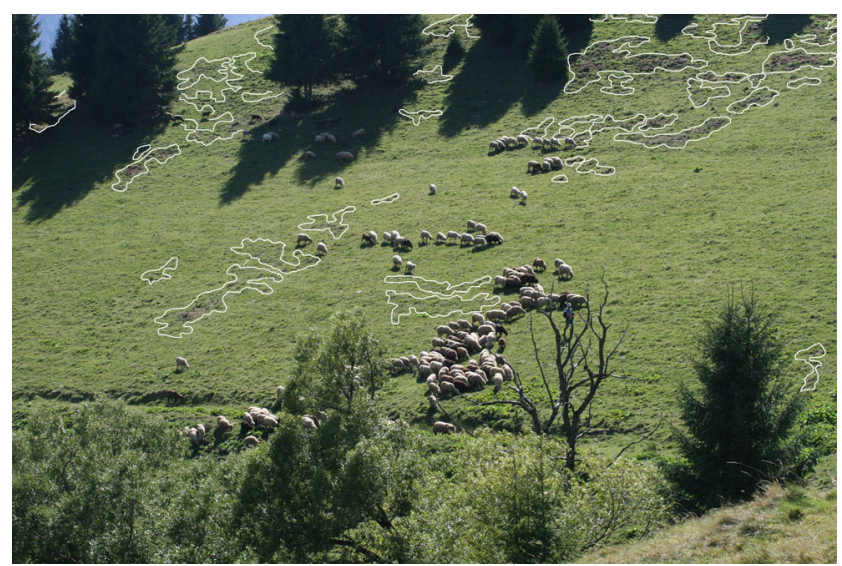

Fig. 2 Alpine pasture used for sheep grazing during the summer months in the Carpathian Mountains, Romania with the areas of swine rooting delineated. (Photo by R. Engeman) 


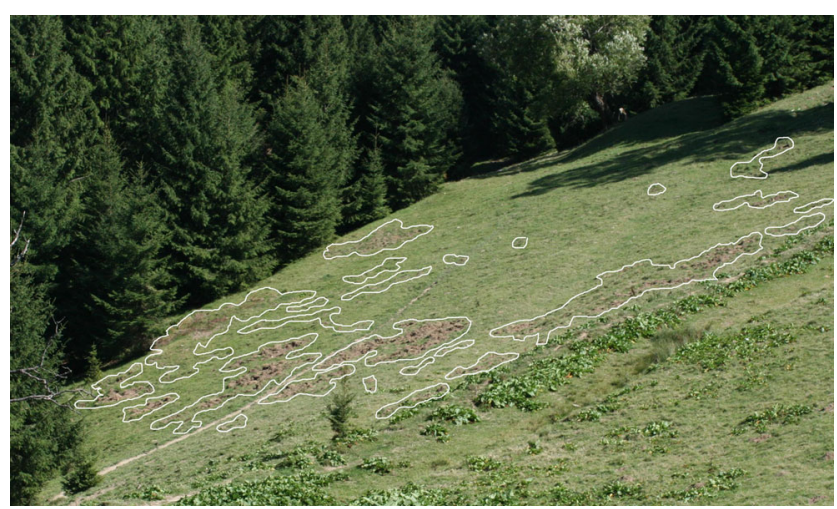

Fig. 3 Alpine pasture used for sheep grazing during the summer months in the Carpathian Mountains, Romania with the areas of swine rooting delineated. (Photo by R. Engeman)

\section{Results and discussion}

The percent damaged (rooted) area calculated for the meadow in Fig. 2 was $11.2 \%$, and the percent damaged calculated for the meadow in Fig. 3 was $13.5 \%$. The damage observed for these pastures was similar to that reported in the Spanish Pyrenees (Bueno et al. 2010) and rivals or exceeds that (observed prior to control programs) in multiple studies of welldocumented feral swine damage to ecologically sensitive wetlands in Florida, USA (e.g., Engeman et al. 2003, 2004, 2007).

Wild boar damage should be considered important to regional grazing concerns in Romania's Carpathian Mountains as pasture land is rented by flock organizers from nearby villages (Mertens and Promberger 2001). Sheep are grazed exclusively on the rented land and grazing density is monitored (Mertens and Promberger 2001). Clearly, extensive rooting devalues the grazing property and de facto elevates the density of sheep for the area of a pasture suitable to be grazed. It also essentially decreases the economic benefit received for the cost of the grazing rights. Because predation is a very visible and tangible loss for livestock growers in the region and has been well-documented (Ionescu et al. 2009; MAPDR and MMGA 2006; Mertens et al. 2001; Predoiu and Ungurean 2010), it would seem that another very visible loss to wildlife in the form of damaged alpine pastureland would receive similar attention. Moreover, alpine grazing pasture losses to wild boar rooting, including economic aspects, have been documented in the literature for various European countries in the Alps and the Pyrenees (Baubet et al. 2004; Bueno et al. 2010; Bueno et al. 2011; Cocca et al. 2007). Thus, we were surprised after our visit to not find literature documenting the very direct costs to livestock owners from significant wild boar rooting within rented pastures in Romania's Carpathian Mountains.

The photographic method we present provides a quick and efficient means to quantify damage to alpine grazing pastures and may have broad application for mountainous areas where swine damage (or other disturbance) occurs and there is sufficient visibility of the damaged habitat. It may not be possible in some cases to photograph a hillside pasture straighton. As we discussed for Fig 3, the perspective, especially along a slope, can influence the proportion of a photograph identified as having damage. Damage beyond the foreground of the photo or down the slope of the hill would make GISmeasured damage areas biased low (conservative, lower bound), while damage found primarily in the foreground would make GIS-measured damage areas biased high (e.g., speculative, upper bound). Thus, the positioning of the camera angle relative to the majority of damage can affect the resulting estimate. (If damage is uniform throughout the area this is not a significant issue). Using the average damage estimate derived from sets of photographs aimed from opposite sides of the pasture might alleviate potential bias.

Our simple, direct approach requires minimal field equipment (camera) and would be suitable for demonstrating the existence and relative amounts of damage and the efficacy of management actions for reducing damage over time. Pattern recognition software that could accurately identify rooting damage in a photograph could potentially offer time-savings by allowing the investigator to automate the delineation of damage patches. This may be more complicated than seems, because the look of rooting damage changes through even a short time period (e.g., Felix et al. 2014) and rooting damage also must be distinguished from natural erosive processes. Extensive testing would be needed to have complete confidence in the accuracy of automating the delineation of damage patches in photographs.

Acknowledgments We wish to gratefully acknowledge Dan Marin, the "Transylvanian Wolf," who guided us and whose exhaustive knowledge of the area's natural history and fluency in English provided us a comprehensive perspective far beyond what we could have logically expected.

\section{References}

Baubet E, Bonenfant C, Brandt S (2004) Diet of the wild boar in the French Alps. ${ }^{\circ}$ especial 16:99-111

Bueno CG, Barrio IC, García-González R, Alados CL, Gómez-García D (2010) Does wild boar rooting affect livestock grazing areas in alpine grasslands? Eur J Wildl Res 56:765-770

Bueno CG, Barrio IC, García-González R, Alados CL, Gómez-García D (2011) Assessment of wild boar rooting on ecological and pastoral values of alpine Pyrenean grasslands. Pirineos Revista de Ecología de Montaña 166:51-67

Cocca G, Sturaro E, Dal Compare L, Ramanzin M (2007) Wild boar (Sus scrofa) damages to mountain grassland. A case study in the Belluno province, eastern Italian Alps. Ital J Anim Sci 6(Suppl 1):845-847

Engeman RM, Smith HT, Shwiff SA, Constantin BU, Nelson M, Griffin D, Woolard J (2003) Prevalence and economic value of feral swine damage to native habitat in three Florida state parks. Environ Conserv 30:319-324

Engeman RM, Smith HT, Severson R, Severson MA, Woolard J, Shwiff SA, Constantin BU, Griffin D (2004) Damage reduction 
estimates and benefit-cost values for feral swine control from the last remnant of a basin marsh system in Florida. Environ Conserv 31:207-211

Engeman RM, Stevens A, Allen J, Dunlap J, Daniel M, Teague D, Constantin BU (2007) Feral swine management for conservation of an imperiled wetland habitat: Florida's vanishing seepage slopes. Biol Conserv 134:440-446

Felix RK Jr, Orzell SL, Tillman EA, Engeman RM, Avery ML (2014) Fine-scale, spatial and temporal assessment methods for feral swine disturbances to sensitive plant communities in south-central Florida. Environ Sci Pollut Res 21:10399-10406

Ionescu O, Ionescu G, Ramon J, Claudiom P, Popa M (2009) Large carnivores in Carpathian Mountains. In: Plassman G, Pavlik M (eds) Large carnivores in the Alps and Carpathians. Alpine Network of Protected Areas, Chambery, France, pp 3-6

MAPDR and MMGA (2006) Management and action plan for the bear population in Romania. Ministry of Agriculture, Forestry, and Rural Development and Ministry of Environment and Water Management, Bucharest, Romania
Mertens A, Gheorghe P, Promberger C (2001) Carnivore damage to livestock in Romania. Carnivore Damage Prevention News 4:10

Mertens A, Promberger C (2000) Problems in damage prevention in Romania. Carnivore Damage Prevention News 2:5-6

Mertens A, Promberger C (2001) Economic aspects of large carnivorelivestock conflicts in Romania. Ursus 12:173-180

Mertens A, Schneider H (2005) What is wrong with Romanian livestock guarding dogs? A discussion. Carnivore Damage Prevention News 9:9-14

Predoiu G, Ungurean S (2010) Analysis of the institutional frame regarding the bear management in Romanian conditions. Bulletin of the Transilvanian University of Brasov 3:49-56

Promberger C, Mertens A (2001) Wolf-livestock conflicts in Romania. International Wolf 11(3):7-8

Thomas J, Engeman RM, Tillman EA, Fischer JW, Orzell SL, Glueck DH, Felix RK Jr, Avery ML (2013) Optimizing line intercept sampling and estimation for feral swine damage levels in ecologically sensitive wetland plant communities. Environ Sci Pollut Res 20: $1503-1510$ 